University of Wollongong

Research Online

Faculty of Business - Papers (Archive)

Faculty of Business and Law

$1-1-2016$

Enacting spiritual leadership in business through ego-transcendence

Lauren Klaus

Department of Education, Employment and Workplace Relations

Mario Fernando

University of Wollongong, mariof@uow.edu.au

Follow this and additional works at: https://ro.uow.edu.au/buspapers

Part of the Business Commons

Research Online is the open access institutional repository for the University of Wollongong. For further information contact the UOW Library: research-pubs@uow.edu.au 


\title{
Enacting spiritual leadership in business through ego-transcendence
}

\author{
Abstract \\ Ethical dilemmas in organisations can arise due to situational circumstances, the decision making \\ process and the conditions in which they are made. Academic literature offers some insights into \\ analysing ethical decision making; these include guidelines on how to deal with ethical dilemmas (e.g. \\ Abramson, 1985; Loewenberg and Dolgoff, 1996; Reamer, 1990). Recently, several prominent corporate \\ scandals have been reported in the media. These include News International Limited, Barclays and BP. \\ According to business ethics scholars, one of the causes for the escalating incidents of corporate \\ scandals is triggered by the weaknesses in the leaders' decision making process. For example, Giacalone \\ and Jurkiewicz (2003) claim that ethical decision making studies have been focused mostly on ethical \\ codes, cultures, and leadership styles. Scholars have shown that ethical codes on its own cannot be relied \\ on to decrease unethical behaviour (e.g. Somers, 2001) and that leadership fails to promote ethical \\ behaviour always (e.g. Victor and Cullen, 1988). More focus is called into looking into the "individual \\ character, personality, and belief systems that may influence ethical cognitions as precursors to \\ behaviour" (Giacalone and Jurkiewicz, 2003, p. 86). One such individual focused approach to improve \\ ethical decision making is based on spiritual leadership.
}

\section{Keywords}

transcendence, business, leadership, spiritual, enacting, ego

Disciplines

Business

\section{Publication Details}

Klaus, L. \& Fernando, M. (2016). Enacting spiritual leadership in business through ego-transcendence. Leadership and Organization Development Journal, 37 (1), 1-34. 
